\title{
A Novel Ilarvirus Is Associated with Privet Necrotic Ringspot Disease in the Southern United States
}

\author{
Nina Aboughanem-Sabanadzovic, Ioannis E. Tzanetakis, Amanda Lawrence, Ronald C. Stephenson, \\ and Sead Sabanadzovic
}

First author: Institute for Genomics, Biocomputing and Biotechnology, Mississippi State, MS 39762; second author: Department of Plant Pathology, Division of Agriculture, University of Arkansas, Fayetteville 72701; third author: Institute for Imaging and Analytical Technologies, Mississippi State University, Mississippi State 39762; fourth author: Coastal Research and Extension Center, Mississippi State University, Biloxi 39532; and fifth author: Department of Biochemistry, Molecular Biology, Entomology and Plant Pathology, Mississippi State University, Mississippi State 39762.

Accepted for publication 17 September 2015.

\begin{abstract}
Aboughanem-Sabanadzovic, N., Tzanetakis, I. E., Lawrence, A., Stephenson, R. C., and Sabanadzovic, S. 2016. A novel ilarvirus is associated with privet necrotic ringspot disease in the southern United States. Phytopathology 106:87-93.

Necrotic ringspot disease (NRSD) is a graft-transmissible disorder of privet (synonym ligustrum), originally reported from Florida and Louisiana more than 50 years ago. In this communication we report an isometric virus isolated from Japanese privet (Ligustrum japonicum) collected in the southern United States displaying symptoms resembling those of NRSD. In mechanical transmission tests, the virus induced systemic infections in

several herbaceous hosts. Double-stranded RNA analysis showed a pattern resembling replicative forms of members of the family Bromoviridae. The genome organization along with phylogenetic analyses and serological tests revealed that the virus belongs to subgroup 1 of the genus Ilarvirus. Pairwise comparisons with recognized ilarviruses indicated that the virus is a distinct, and as yet, undescribed member in the taxon, for which we propose the name Privet ringspot virus (PrRSV). Furthermore, the nearperfect association of PrRSV infections with symptoms, and apparent absence of any other virus(es) in studied samples, strongly suggest an important role of this virus in the etiology of NRSD of privet in the southeastern United States.
\end{abstract}

Japanese privet (syn. Japanese ligustrum or glossy privet; Ligustrum japonicum Thunb., fam. Oleaceae) is an evergreen shrub/small tree native to Asia. Being relatively easy to grow, it is now commonly used as an ornamental shrub and for hedgerows in many areas of the world, including the southern United States where it was introduced in the 1800s. Privet is attacked by several insect pests and pathogens, including viruses. Indeed, several viruses, especially members of the genus Nepovirus, have been reported from different Ligustrum species (Blaszczak and Pospieszny 1987; Cadman 1961; Dupuis et al. 2008; Thomsen 1970).

The first graft-transmissible disease of Ligustrum spp. was reported in Germany more than 100 years ago and referred to as "infectious chlorosis" affecting L. vulgare (common privet; Baur 1907). Similar graft-transmissible diseases were described in the 1950s, such as ringspot of ligustrum/privet on L. ovalifolium Hassk. in Texas (Hildebrand 1953) and chlorotic spot disease of Japanese privet in the Baton Rouge area, Louisiana (Plakidas 1959). A few years later necrotic ringspot disease was reported in 20 counties in Florida (Burnett and Youtsey 1962). After an exchange of infected materials, the authors concluded that the Louisiana and Florida plants were affected by the same disease, characterized by the presence of ring spots, irregular line patterns and foliar deformations, and proposed the common name necrotic ringspot disease (NRSD) (Burnett and Youtsey 1962). Despite the fact that the original authors demonstrated graft-transmissibility, no causal agent has yet been identified. Ligustrum necrotic ringspot virus (LNRSV), a carlavirus,

Corresponding author: S. Sabanadzovic, E-mail address: ss501@msstate.edu

*The $\boldsymbol{e}$-Xtra logo stands for "electronic extra" and indicates that one supplementary table and two supplementary figures are published online.

http://dx.doi.org/10.1094/PHYTO-12-14-0387-R

(C) 2016 The American Phytopathological Society was reported from a single diseased plant from South Carolina (Scott and Zimmerman 2008), but its possible role in the disease was never confirmed. Therefore, at present, the causal agent of the privet NRSD remains unknown.

Another disease characterized by leaf ringspots of $L$. lucidum was reported from Argentina (Vergani 1942) and Brazil (Bitancourt 1955) under the name lepra explosiva. Ultrastructural studies identified bacilliform particles and electron-dense viroplasms in the cytoplasm of infected leaf cells (Da Costa Lima et al. 1991). The putative agent of the disease, a virus named Ligustrum ringspot virus (LigRSV), was experimentally transmitted by the mite Brevipalpus phoenicis (Da Costa Lima et al. 1991; reviewed by Kitajima et al. $2003 ; 2010)$ and partially sequenced. The sequence data indicated that LigRSV is likely a yet undescribed species in the genus Cilevirus.

Symptoms resembling necrotic ringspot diseases were initially observed on a group of privet plants in north-central Mississippi in 2011. Given the documented presence of NRSD in the southern United States for more than 50 years and the fact that no agent has been reported, we characterized its putative cause, a yet unknown ilarvirus.

The genus Ilarvirus (family Bromoviridae) includes more than 20 recognized or tentative members that are transmitted efficiently by seed, pollen and pollen-feeding insects. They have icosahedral or semi-icosahedral virions of 25 to $35 \mathrm{~nm}$ and a genome comprised of three single-stranded positive strand RNA molecules (Bujarski et al. 2012). The genome encodes for four or five proteins, which are expressed from capped genomic or subgenomic RNAs. Genomic RNA 1 in all ilarviruses is monocistronic and encodes protein 1a, which has methyltransferase and helicase activity (Pallas et al. 2012). In the majority of ilarviruses, RNA 2 is also monocistronic, encoding protein $2 \mathrm{a}$, an alphavirus superfamily-type RNA-dependent RNA polymerase, which in association with protein 1a forms the viral replicase. However, some species have a small open reading frame (ORF) that partially overlaps $2 \mathrm{a}$ and encodes an RNA interference 
suppressor (Bujarski et al. 2012; Pallas et al. 2012; Shimura et al. 2013). RNA 3 is bicistronic with the $5^{\prime}$-proximal ORF encoding for a virus movement protein and a 3 '-proximal ORF, coding for the virus coat protein, which is expressed via a subgenomic RNA (Codoñer and Elena 2008).

The presence of the new virus in the initial samples showing necrotic ringspot symptoms prompted further investigation and characterization of the privet ilarvirus, tentatively named Privet ringspot virus (PrRSV).

\section{MATERIALS AND METHODS}

Virus sources and experimental host range. The type isolate was characterized from a symptomatic Japanese privet plant, referred to as 'Win-01' that was collected in north-central Mississippi in 2011. Virus transmission was performed by extracting young symptomatic leaves into cold $0.1 \mathrm{M}$ phosphate buffer, $\mathrm{pH} 7.2$ (1:10, wt/vol, ratio). The slurry was gently rubbed onto Celite-dusted leaves of several herbaceous plants. Tissue from Nicotiana occidentalis, infected in the initial experiment was used as the virus source for a second round of mechanical transmission to other species. The plants used to study the host range of the virus were as follows: $N$. occidentalis; $N$. tabacum 'Turkish'; N. benthamiana; Capsicum annuum 'Sweet banana'; Chenopodium quinoa; Phaseolus vulgaris 'Black Valentine', 'Bountiful', and 'Kentucky Wonder'; Vigna unguiculata 'Purplehull Big Boy'; Glycine max 'AG 4632' and 'AG5322'; Cucumis sativus 'Straight Eight' and 'Long Green'; Citrullus lanatus 'Black Diamond' and 'Crimson Sweet'; and Cucurbita pepo 'Gray Squash' and 'JackO'Lantern'. Each species/cultivar was represented by at least five replicates. Inoculated plants were kept in an insect-proof, temperaturecontrolled greenhouse at 18 to $22^{\circ} \mathrm{C}$ under natural light and were checked daily for symptom appearance for a total period of 1 month. The presence or absence of asymptomatic infections was ascertained by back inoculations of two plants per species/cultivar to N. occidentalis.

Double-stranded RNAs. Double-stranded RNAs (dsRNAs) were isolated from $20 \mathrm{~g}$ of foliar tissue of privet Win-01 and infected
$N$. occidentalis plants using phenol/chloroform extraction and cellulose column chromatography were combined with silica capture method. Further purification was achieved by selective treatments with DNAse, RNAse A (in high salt conditions), and Proteinase $\mathrm{K}$ as previously described (Sabanadzovic and Abou GhanemSabanadzovic 2008). Purified dsRNAs were analyzed in $1.5 \%$ Tris-acetate-EDTA (TAE) agarose electrophoresis under native conditions and visualized under UV after staining with ethidium bromide. Extracts from a pepper plant coinfected with Bell pepper endornavirus (BPEV; genus Endornavirus, family Endornaviridae) and Peanut stunt virus (PSV; genus Cucumovirus, family Bromoviridae) were used as references.

Virus purification. Fifty grams of foliar tissue from Win-01 was homogenized in a blender with 3 volumes of ice-cold extraction buffer $(0.1 \mathrm{M} \mathrm{K} / \mathrm{Na}$ phosphate buffer, $\mathrm{pH} 7.2$, containing $0.1 \%$ thioglycolic acid), filtered through four layers of cheesecloth and clarified by adding $7 \%$ (vol/vol) n-butanol followed by low speed centrifugation $\left(15,000 \times g\right.$ for $10 \mathrm{~min}$ at $\left.4^{\circ} \mathrm{C}\right)$. The upper phase was collected and the virus was sedimented by centrifuging $1.75 \mathrm{~h}$ at $78,000 \times g$ at $4^{\circ} \mathrm{C}$. Virus-containing pellets were resuspended in $0.02 \mathrm{M} \mathrm{K} / \mathrm{Na}$ phosphate buffer, $\mathrm{pH}$ 7.0. Formvar/carbon coated copper grids (300 mesh) containing partially purified virus preparations were negatively stained with $2 \%$ uranyl acetate and observed with a JEOL JEM-1230 transmission electron microscope (TEM).

Cloning, sequencing, and sequence analyses. Purified dsRNAs were heat denatured at $95^{\circ} \mathrm{C}$ for $5 \mathrm{~min}$, cooled on ice, randomprimed, and reverse transcribed as described by Froussard (1992) with modifications (Sabanadzovic et al. 2009). The resulting cDNA was size selected with Illustra MicroSpin S-400 HR columns (GE Healthcare, Pittsburgh, PA) and cloned into pGEM-T Easy plasmid (Promega, Madison, WI). Recombinant plasmids were transfected into Escherichia coli top 10 competent cells (Invitrogen, Grand Island, NY) and sequenced. Initial sequence data were assembled and mapped with the DNAStar Lasergene package (DNASTAR Inc., Madison, WI).
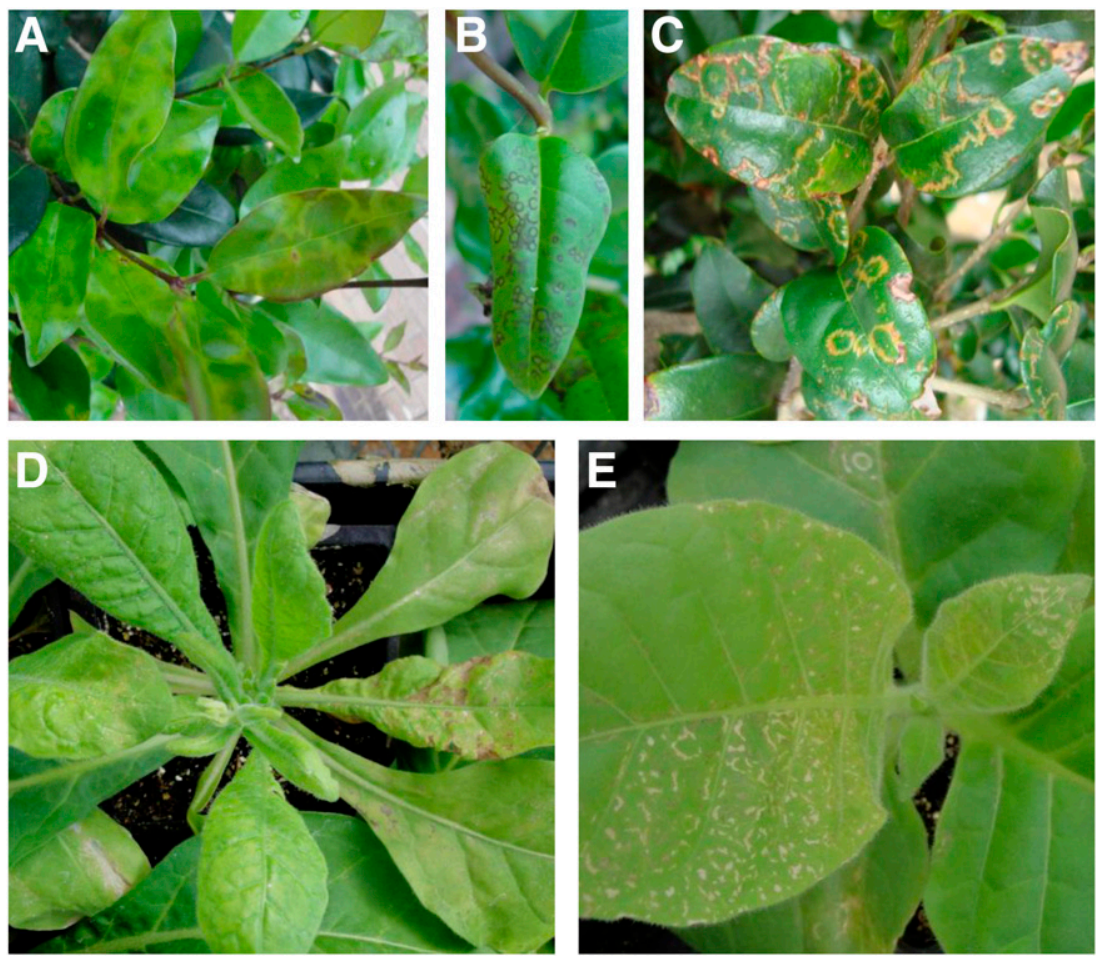

Fig. 1. Symptoms associated with privet ringspot disease (PRSD). Irregular line patterns and/or ringspots on $\mathbf{A}$ and $\mathbf{B}$, young and $\mathbf{C}$, mature leaves of infected privet plants collected from central and southern Mississippi. Systemic symptoms caused by Privet ringspot virus in D, Nicotiana occidentalis and E, N. tabacum Turkish 2 weeks postinoculation. 
Gaps between adjacent clones were filled using reverse transcription polymerase chain reaction (RT-PCR) with virus-specific primers designed on the initial sequence data. Nucleotide sequences of viral termini were determined by RACE-PCR using GeneRacer (Invitrogen). In order to get a consensus sequence for PrRSV, multiple overlapping clones were sequenced to achieve at least eight times coverage of each nucleotide. The complete genome sequence was compared with those of known ilarviruses using the pairwise sequence comparison (PASC) resource available at the NCBI (Bao et al. 2014). Conserved domains in putative products of the virus genome were identified with BLAST (Altschul et al. 1997) and Conserved Domain Database (Marchler-Bauer et al. 2013). Multiple alignments were performed with Muscle (Edgar 2004) and regions of poor alignments and gaps were eliminated with GBlocks (Castresana 2000; Talavera and Castresana 2007). Phylogenetic relationships of the PrRSV RNA-dependent RNA polymerase with other ilarviruses were inferred with the maximum likelihood method based on the LG+G substitution model (Le and Gascuel 2008), implemented in MEGA v.6.06 software (Tamura et al. 2013).

Serology. Serological relationships between PrRSV and other ilarviruses were investigated with western and immunodot-blot assays using polyclonal antisera produced in rabbits against Tobacco streak virus (anti-TSV), Parietaria mottle virus (antiPMoV), and Strawberry necrotic shock virus (anti-SNSV). Antisera to TSV and PMoV were kindly provided by S. Scott (Clemson

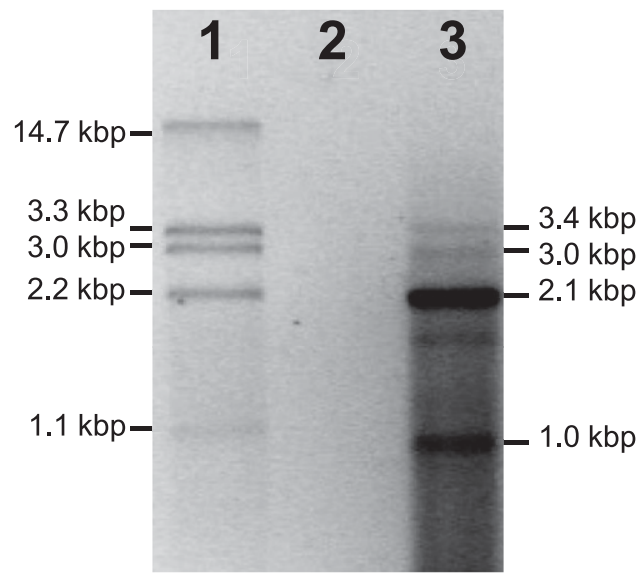

Fig. 2. Electrophoretic patterns of Privet ringspot virus (PrRSV)-associated double-stranded (ds)RNAs. The molecular markers represented by the mixture of dsRNAs extracted from plants infected by Peanut stunt virus (PSV; genus Cucumovirus, family Bromoviridae) and Bell pepper endornavirus (BPEV; genus Endornavirus, family Endornaviridae) are in lane 1. No visible dsRNAs are present in mock-inoculated Nicotiana occidentalis (lane 2). Replicative forms of PrRSV extracted from symptomatic $N$. occidentalis plants are in lane 3. Estimated sizes of putative PrRSV-associated dsRNA molecules are indicated.
University), while anti-SNSV was a generous gift from R. Martin (USDA-ARS). Both tests were performed on total protein extracts from PrRSV-infected $N$. occidentalis, TSV-infected bean and SNSV-infected strawberry, as described (Tzanetakis et al. 2004). All antisera were diluted 1:1,000 in PBS and incubated for $1 \mathrm{~h}$ at room temperature. Membranes were washed three times in PBS-Tween $2 \%$, prior to incubation for $1 \mathrm{~h}$ with goat anti-rabbit alkaline phosphatase conjugate (Sigma) diluted 1;2,000 in PBS buffer containing $2 \%$ PVP and $0.2 \%$ nonfat milk. Reactions were visualized by soaking membranes in a solution of nitroblue tetrazolium (NBT) and 5-bromo-4-chloro-3-indolyl phosphate (BCIP) in substrate buffer (0.1 M Tris, 0.1 M NaCl, and $\left.5 \mathrm{mM} \mathrm{MgCl}_{2}, \mathrm{pH} 9.5\right)$.

Search for additional viruses in infected samples. In order to ascertain if additional viruses were present in infected plants, we performed multiple RT-PCR tests on eight representative privet samples from Mississippi and Louisiana showing symptoms of the disease (two from the original location, three from southern MS, and three from Baton Rouge, LA), as well as two symptomless plants. Briefly, we performed RT-PCR with degenerate primers for the following taxa: (i) como/nepoviruses (Maliogka et al. 2004), (ii) closteroviruses (Tian et al. 1996), (iii) flexiviruses (Dovas and Katis 2003), and (iv) tymo/marafiviruses (Sabanadzovic et al. 2009) as described in the original papers. The possible presence of potyviruses in affected samples was ascertained by enzyme-linked immunosorbent assay (ELISA) using the potyvirus group specific monoclonal antibody (Agdia Inc., IN).

Samples were also assayed for LNRSV and LigRSV. For each of these two viruses we performed two independent RT-PCR experiments using different primer sets (Supplementary Table S1). In addition, transmission electron microscopic (EM) observations were performed on eight thin sections from two diseased privet plants prepared according to the protocol of Martelli and Russo (1984). Briefly, foliar tissue was fixed with $2.5 \%$ glutaraldehyde in

TABLE 1. Nucleotide and amino acid sequence identities of Privet ringspot virus with orthologs in the subgroup 1 of the genus Ilarvirus ${ }^{\mathrm{a}}$

\begin{tabular}{lccccc}
\hline & TSV & PMoV & BaCV* $^{*}$ & BCRV & SNSV \\
\hline Nucleotides & & & & & \\
RNA 1 & 72 & 68 & $68^{*}$ & 72 & 72 \\
RNA 2 & 71 & 70 & $72^{*}$ & 71 & 70 \\
RNA 3 & 69 & 65 & 64 & 69 & 71 \\
Amino acids & & & & & \\
p1 & 69 & 66 & 67 & 73 & 73 \\
p2a & 68 & 68 & $72^{*}$ & 67 & 68 \\
p2b & 50 & 52 & 49 & 51 & 48 \\
p3a & 72 & 65 & 59 & 67 & 74 \\
p3b & 58 & 42 & 51 & 49 & 59 \\
\hline
\end{tabular}

a Pairwise identities were calculated with ClustalW. Abbreviations: Tobacco streak virus (TSV), Parietaria mottle virus (PMoV), Bacopa chlorosis virus $(\mathrm{BaCV})$, Blackberry chlorotic ringspot virus (BCRV), and Strawberry necrotic shock virus (SNSV). Asterisk (*) indicates only partial sequence data available (3,196 nt for RNA 1 and 1,780 nt for RNA 2).

RNA1 (3415 nt)

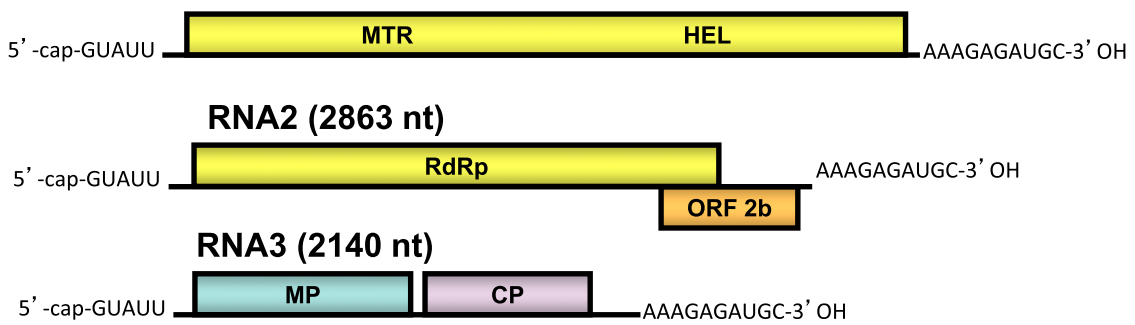

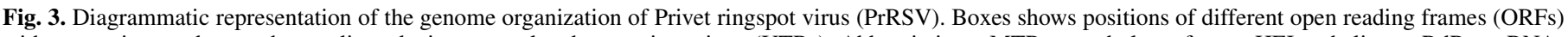

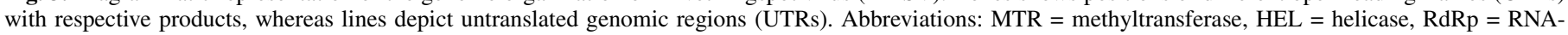

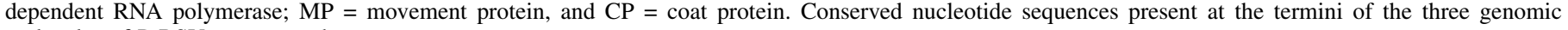
molecules of PrRSV are reported. 
$0.05 \mathrm{M}$ phosphate buffer, $\mathrm{pH} 7.2$, postfixed in $2 \%$ osmium tetroxide, and gradually dehydrated in ethanol prior to embedding in Spurr's resin. Before TEM examinations, ultra-thin sections were cut on a Reichert-JUNG UltracutE microtome and stained with uranyl and lead citrates.

Association of the virus with ringspot disease. A single tube RT-PCR assay was developed in order to study the incidence of the virus and its association with the ringspot disease. A total of 80 symptomatic and symptomless privet samples were collected from several locations in Mississippi (Supplementary Fig. S1) and Baton Rouge, LA. Total RNA was extracted from $0.1 \mathrm{~g}$ of young foliar tissue using the Plant Mini RNA kit (Qiagen, Valencia, CA) and used for single tube RT-PCR test with SuperScript III One-Step RTPCR System with Platinum Taq High Fidelity kit (Invitrogen). To this purpose, $3 \mu$ l of total RNA was mixed with 12.5 - $\mu$ l reaction buffer, $3 \mu \mathrm{l}$ of $5 \mathrm{mM} \mathrm{MgSO}_{4}, 1 \mu \mathrm{l}$ of each of the primers (PRS-1300F 5'-CAAAGACAGTCGATACTAACGA-3' and PRS-1830R 5'GCCCGTTGTTCATACGAACA- $3^{\prime}$ ), $0.5 \mu \mathrm{l}$ of RT/Taq mix, and $4 \mu \mathrm{l}$ of RNase-free water for a total volume of $25 \mu \mathrm{l}$. This mix was then subjected to reverse transcription for $20 \mathrm{~min}$ at $50^{\circ} \mathrm{C}$, followed by denaturation for $2 \mathrm{~min}$ at $94^{\circ} \mathrm{C}$, and 40 cycles of PCR $\left(94^{\circ} \mathrm{C}\right.$ for $20 \mathrm{~s}, 53^{\circ} \mathrm{C}$ for $30 \mathrm{~s}$, and $68^{\circ} \mathrm{C}$ for $45 \mathrm{~s}$ ) terminated with a final elongation at $72^{\circ} \mathrm{C}$ for $7 \mathrm{~min}$. Primer set PRS-1300F/PRS-1830R was designed to amplify a 523-bp segment of RNA 3.

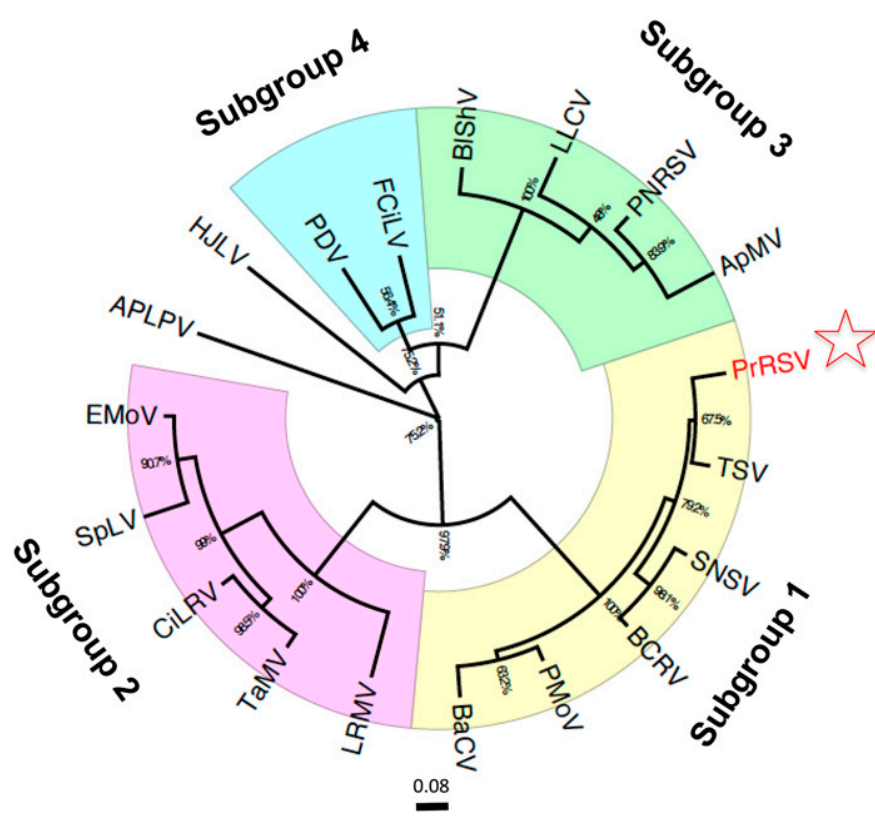

Fig. 4. Phylogenetic tree constructed on viral RNA-dependent RNA polymerases of Privet ringspot virus (PrRSV) and recognized/tentative members of the genus Ilarvirus. The evolutionary history was inferred by maximum likelihood method implemented in MEGA 6.06 (Tamura et al. 2013) and based on LG+G substitution model (Le and Gascuel 2008). The positions containing gaps and missing data were eliminated. The clades containing four different ilarvirus subgroups are shaded and indicated. A star indicates the position of PrRSV. The bootstrap method based on 1,000 pseudoreplicates was used to assess the statistical reliability of the constructed tree. The names, acronyms, and GenBank accession numbers of sequence data used in this analysis are as follows (in alphabetical order): American plum line pattern virus (APLPV, NC_003452), Apple mosaic virus (ApMV, NC_003465), Bacopa chlorosis virus (BaCV, FJ607141), Blackberry chlorotic ringspot virus (BCRV, NC_011554), Blueberry shock virus (B1ShV, YP_008519305), Citrus leaf rugose virus (CiLRV, NC_003547), Elm mottle virus (EMoV, NC_003568), Fragraria chiloensis latent virus (FCILV, NC_006567), Humulus japonicus latent virus (HJLV, NC 006065), Lilac leaf chlorosis virus (LLCV, YP_009104368), Lilac ring mottle virus (LRMV, NC_003568), Parietaria mottle virus (PMoV, NC_005849), Prune dwarf virus (PDV, NC_008037), Prunus necrotic ringspot virus (PNRSV, NC_004363), Spinach latent virus (SpLV, NC_003809), Strawberry necrotic shock virus (SNSV, NC_008707), Tobacco streak virus (TSV, NC_003842), and Tulare apple mosaic virus (TaMV, NC_003834).
Results were examined by electrophoresis in $1.5 \%$ TAE agarose gels and visualized under UV light after staining with GelRed (Biotium Inc., Hayward, CA). The validity of RT-PCR results was confirmed by sequencing of 14 randomly chosen RT-PCR products generated from samples collected in north-central and southern MS, as well as in Baton Rouge, LA.

\section{RESULTS}

Symptomatology. Symptoms observed on privet plants varied slightly depending on the location and time of sampling. Typically, we observed chlorotic line patterns and ringspots on young leaves (Fig. 1A) that become necrotic later in the season (Fig. 1B and C). In some instances affected leaves were deformed and reduced in size. Symptoms were often visible only on a portion of the canopy and were more pronounced in cooler weather (early spring and late fall) than during the summer.

In mechanical transmission tests, 4 of 11 tested plant species/varieties were susceptible to PrRSV. Symptoms included localized chlorosis that appeared 7 days postinoculation (dpi) on inoculated leaves of $N$. occidentalis plants, followed by severe systemic necrosis of the apical foliage 14 dpi (Fig. 1D). Inoculated N. tabacum Turkish plants developed systemic necrotic line patterns (Fig. 1E). Similar symptoms were associated with systemic infections in $N$. benthamiana. Infected Chenopodium quinoa plants displayed systemic chlorosis followed by deformation of the apical leaves approximately 2 weeks postinoculation (not shown). No other plants developed visible symptoms within 45 dpi with, nor did they induce symptoms on back-inoculated N. occidentalis plants.

Virus purification and dsRNA extraction. Partially purified virions from symptomatic $N$. occidentalis revealed the presence of quasi-isometric particles of ca. 25 to $30 \mathrm{~nm}$ in diameter (Supplementary Fig. S2) interpreted as PrRSV virions. These particles were not present in extracts from healthy (mock-inoculated) $N$. occidentalis plants processed in the same manner. Similar particles were observed in partially purified virions from young foliar tissue of two infected privet plants.

Extraction of dsRNAs from infected Japanese privet Win-01 and $N$. occidentalis yielded identical patterns consisting of multiple bands, reminiscent of replicative forms of members of the family Bromoviridae (Fig. 2 and not shown). By comparison with mobility rates of the reference markers (Fig. 2, lane 1) their molecular size was estimated at ca. 3.4, 3.0, 2.1, and $1.0 \mathrm{kbp}$. No visible dsRNAs were observed in extracts from asymptomatic controls of $N$. occidentalis (Fig. 2, lane 2) and privet (not shown).

Genome organization and phylogenetics. The genome of the virus consists of three ssRNA molecules of different size, which all share the first five and the last 10 nucleotides including the 'AUGC' tetranucleotide conserved at the extreme 3 ' end in genomes of many ilarviruses and Alfalafa mosaic virus (Fig. 3).

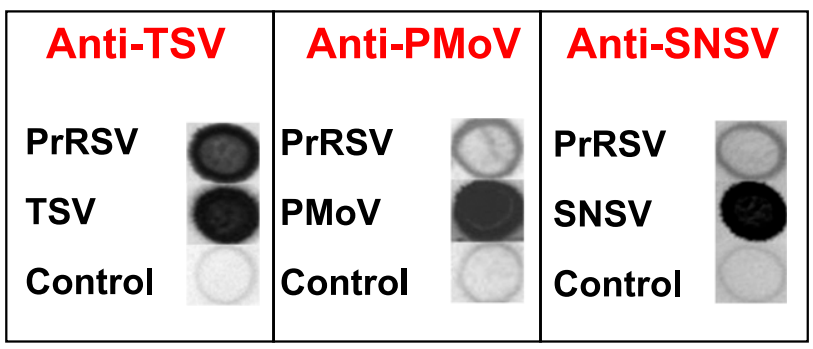

Fig. 5. Immuno-dot blot tests of Privet ringspot virus (PrRSV) and ilarviruses of subgroup 1. The antisera used are indicated above each panel. Total proteins from PrRSV-infected Nicotiana occidentalis are in the first row, antigens homologous to each antisera are in the second row, and negative controls are in the third row. Abbreviations: $\mathrm{TSV}=$ Tobacco streak virus, $\mathrm{PMoV}=$ Parietaria mottle virus, and SNSV = Strawberry necrotic shock virus. 
RNA 1 (3,415 nt; GenBank Accession KT290039) contains an ORF that encodes a 1,095 amino acid (aa)-long protein with molecular mass of $124 \mathrm{kD}$. The predicted protein has sequence similarity to methyltransferase motifs between residues 88 and 281 (Rozanov et al. 1992) and an RNA helicase domain between residues 806 and 1,053 (Gorbalenya et al. 1989). The protein has more than $65 \%$ aa identity and $80 \%$ similarity to the replicases of the recognized or tentative members of the genus Ilarvirus subgroup 1 (Table 1).

RNA 2 (2,863 nt; GenBank accession KT290040) is bicistronic with the two ORFs overlapping by $257 \mathrm{nt}$. The ORF at the 5' proximal end of the molecule (2a) codes for a 799 aa protein with predicted molecular mass of $92 \mathrm{kD}$, whereas the second ORF (2b) encodes a 199 aa protein with predicted molecular mass of $22 \mathrm{kD}$. Protein encoded by the ORF2a has signature RNA-dependent RNA polymerase (RdRp) motifs between residues 390 and 633 (Koonin 1991) and shares more than $65 \%$ aa identity and about $80 \%$ similarity to the polymerase of the recognized or tentative members of subgroup 1 . The $2 \mathrm{~b}$ protein shares only 48 to $52 \%$ identities with its orthologs found in all members of subgroup 1 and 2 and Lilac ring mottle virus (Table 1).

Genomic RNA 3 (2,140 nt; GenBank accession KT290041) contains two ORFs. ORF 3a encodes a 293-aa-long protein with an estimated molecular mass of $32 \mathrm{kD}$, and ORF $3 \mathrm{~b}$ codes for a putative 222 aa protein with predicted molecular mass of $25 \mathrm{kD}$. The $3 \mathrm{a}$ protein has more than $65 \%$ sequence identity and $80 \%$ similarity with the movement proteins from ilarviruses subgroup 1 . The $3 \mathrm{~b}$ protein $(25 \mathrm{~K})$ is most closely related to the coat protein of TSV (about $60 \%$ aa identity and $70 \%$ similarity).

Maximum likelihood based phylogenetic analyses of viral RdRp, performed with MEGA 6.06 under the best fit substitution model $(\mathrm{LG}+\mathrm{G})$, placed PrRSV in a clade comprising recognized and tentative species of the subgroup 1 in the genus Ilarvirus (Fig. 4 and not shown). Grouping of PrRSV with recognized species of the ilarvirus Subgroup 1 was supported by perfect bootstrap values $(100 \%)$ calculated out of 1,000 replicates. The tree generated with the Bayesian method had essentially the same topology (not shown).

Serology. In serological tests performed in this work, western and immunodot-blots total protein extracts from Win-01 reacted with antisera to TSV, PMoV, and SNSV (Fig. 5 and not shown) at the tested dilutions $(1: 1,000)$, revealing serological relationships of the virus infecting privet with ilarviruses belonging to subgroup 1 . The strongest reaction was with anti-TSV antibodies; the results that are in agreement with results of pairwise comparisons of coat protein sequences with members of subgroup 1 and with phylogenetic analyses.

Search for other viruses in diseased plants. Experiments aimed to identify additional viruses included virus- (i.e., LigRSV, LNRSV) or universal, taxon-specific (flexivirid-, closterovirid-, tymovirid-specific, etc.) RT-PCR and potyvirus-specific ELISA tests. No viruses other than PrRSV were identified in Win-01 and other seven representative samples collected from two distinct locations in MS (Hancock County and Oktibbeha County) and Baton Rouge (LA).

Electron microscopy of partially purified virions from Win-01 and another PrRSV-infected plant from southern MS contained only scattered quasi-isometric particles similar to those purified from mechanically inoculated $N$. occidentalis plants. Finally, electron microscopy of thin sections of Win- 01 and an additional symptomatic sample from southern MS (four sections/grids each), did not reveal any cytoplasmic structures comparable to viroplasms that are associated with privet infections by cileviruses in Brazil (Kitajima et al. 2003).

Association of PrRSV and the disease. The absence of additional viruses in NRSD-affected samples prompted a study aimed to investigate the possible involvement of PrRSV in the disease of privet/ligustrum. A virus-specific one step RT-PCR procedure was developed and applied to investigate possible involvement/association of PrRSV in the etiology of the NRSD of privet (Fig. 6).

PrRSV was present in a total of 55 of 80 privet samples (52 symptomatic, 28 asymptomatic) collected from different locations in Mississippi and Baton Rouge, LA (Table 2). The virus-specific PCR products were obtained from all 52 symptomatic samples tested in this survey. PrRSV was also detected in 3 of 28 apparently asymptomatic privet samples collected in Mississippi. Besides Japanese privet, PrRSV was also present in two samples of $L$. amurense, collected from the same location as Win-01. Sequencing of 14 amplicons generated from PrRSV isolates collected from three different geographic locations showed high sequence conservation in the target genome portion, as all studied isolates shared more than $98 \%$ identical nucleotides.

\section{DISCUSSION}

Ringspot of privet/ligustrum is a graft-transmissible disease originally reported from Florida and Louisiana in the 1960s (Plakidas 1959; Burnett and Youtsey 1962) and presumably present elsewhere in the southern United States. Despite the fact that the disease has been known for more than 50 years, and that original study indicated its possible viral origin, the causal agent remained elusive. This prompted our study of NRSD, which led to identification of a mechanically transmissible virus in the original set of diseased plants and its further characterization.

The virus characterized in this study is a new ilarvirus with highest similarity to TSV. According to the most recent list of officially recognized virus species released by the International Committee on Taxonomy of Viruses (ICTV) (http://talk.ictvonline. org/files/ictv_documents/m/msl/4911.aspx), the genus Ilarvirus of the family Bromoviridae contains 19 recognized species. Differences

TABLE 2. Geographic origin of privet samples tested for the presence of Privet ringspot virus using one-step reverse transcription polymerase chain reaction assay

\begin{tabular}{lccc}
\hline Geographic origin & Tested & Positive/symptoms & Negative \\
\hline Carroll County, MS & 14 & $14 / 14^{\mathrm{a}}$ & - \\
Oktibbeha County, MS & 11 & $3 / 3$ & 8 \\
Lauderdale County, MS & 11 & $5 / 4$ & 6 \\
Jackson/George County, MS & 6 & $4 / 4$ & 2 \\
Franklin County, MS & 6 & $2 / 2$ & 4 \\
Hancock/Pearl River County, MS & 19 & $19 / 17$ & - \\
Lee/Pontotoc County, MS & 7 & $2 / 2$ & 5 \\
Baton Rouge, LA & 6 & $6 / 6$ & - \\
Total & 80 & $55 / 52$ & 25 \\
\hline
\end{tabular}

a Samples included two plants of Ligustrum.

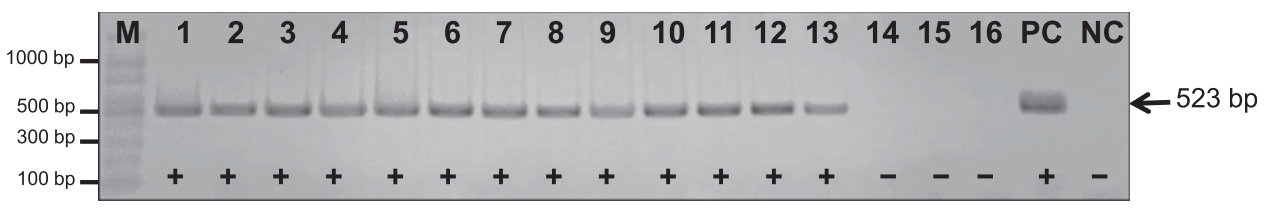

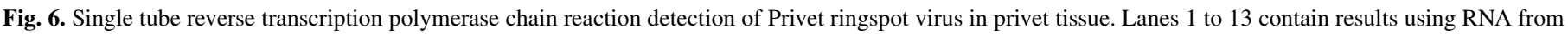

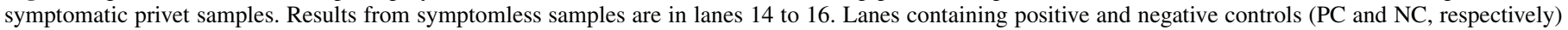
are indicated. Lane M contains reference DNA markers (100-bp ladder). 
in serology, host range, and genomic sequences (without specifying the thresholds) are currently used for species demarcation within the genus Ilarvirus proposed by the ICTV Bromoviridae Study Group. The virus identified in this study fulfills all of these features: (i) it is serologically related to, but distinct from other viruses belonging to subgroup 1 of the genus Ilarvirus; (ii) it infects Ligustrum spp., not reported to host any of the known ilarviruses; and (iii) it is molecularly and phylogenetically related to, but distinct, from all currently recognized species in the genus. Hence, the studied virus has general features of ilarviruses, but is different than any currently known virus from this taxonomic group.

The results of this study strongly suggest that the novel ilarvirus is implicated in the etiology of privet (ligustrum) ringspot disease and, most likely, is the cause of disease. This is supported by the very close association of this virus with the disease in privet collected in Mississippi. As ascertained by virus-specific RT-PCR, all symptomatic samples collected in several locations were infected with PrRSV. The presence of PrRSV in three plants showing no obvious symptoms could be explained by an initial stage of virus infection (prior to symptom development), seasonal variation in symptom expression or possible tolerance differences in particular privet genotypes. Nevertheless, partial sequencing of 14 PrRSV isolates from distinct geographic locations indicates a rather homogenous population.

The hypothesis of the involvement of this virus in NRSD has been further strengthened by the detection of the virus in all symptomatic privet samples collected from two locations in Baton Rouge (LA), where privet (ligustrum) ringspot disease was originally described (Plakidas 1959). We did not test samples from Florida in this study.

A range of molecular (random cloning, dsRNA analysis, several taxon-specific RT-PCR tests, etc.), biological (mechanical transmission), electron microscope tests (repeated observations of partially purified preparations) as well as immunoassays failed to identify any other virus(es) in several studied NRSD-affected samples. Particular attention has been given to verify the possible presence of LNRSV (a carlavirus reported from a single symptomatic sample in South Carolina; Scott and Zimmerman 2008) and a putative cilevirus associated with lepra explosiva in Argentina and Brazil (Da Costa Lima et al. 1991; Kitajima et al. 2003; 2010). Neither of the two viruses could be detected in any of several tested symptomatic samples, suggesting that they are not involved in NRSD.

We have reported characterization of a previously undescribed virus in the genus Ilarvirus. We propose the name Privet ringspot virus (PrRSV) for this virus in order to distinguish it from previously described LNRSV (genus Carlavirus, family Betaflexiviridae) and LigRSV (putative member of the genus Cilevirus) (Scott and Zimmerman 2008). The presence of PrRSV was highly correlated with the NRSD of privet, suggesting an important role for the virus in the etiology of the disease in the southern United States.

\section{ACKNOWLEDGMENTS}

This work was partially supported by Special Research Initiative funds from Mississippi Agricultural and Forestry Experiment Station (MAFES) of Mississippi State University. We thank R. A. Valverde (Louisiana State University), R. R. Martin (USDA-ARS, Corvallis, OR), and S. W. Scott (Clemson University) for kindly providing valuable materials used in parts of this research.

\section{LITERATURE CITED}

Altschul, S. F., Madden, T. L., Schäffer, A. A., Zhang, J., Zhang, Z., Miller, W., and Lipman, D. J. 1997. Gapped BLAST and PSI-BLAST: A new generation of protein database search programs. Nucleic Acids Res. 25: 3389-3402.

Bao, Y., Chetvernin, V., and Tatusova, T. 2014. Improvements to pairwise sequence comparison (PASC): A genome-based web tool for virus classification. Arch. Virol. 159:3293-3304.

Baur, E. 1907. Ueber infektiose chlorosen bei Ligustrum, Laburnum, Fraxinus, Sorbus und Ptelea. Ber. d. deutsch. bot. Gesel. 25:410-423.
Bitancourt, A. A. 1955. Estudos sobre a leprose dos citrus. Arq. Inst. Biol. (Sao Paulo) 22:161-231.

Blaszczak, W., and Pospieszny, H. 1987. Ligustrum vulgare L.-a natural host of the tomato black ring virus. Pr. Nauk Inst. Ochr. Rosl. 29:127-136.

Bujarski, J., Figlerowicz, M., Gallittelli, D., Roossinck, M. J., and Scott, S. W. 2012. Family Bromoviridae. Pages 965-976 in: Virus Taxonomy, Ninth Report of the International Committee on Taxonomy of Viruses. A. King, M. J. Adams, E. B. Carstens, and E. Lefkowitz, eds. Elsevier-Academic Press, Amsterdam.

Burnett, H. C., and Youtsey, C. O. 1962. Necrotic ringspot, a virus disease of Ligustrum sp. Fla. St. Hortic. Soc. 75:472-476.

Cadman, C. H. 1961. Virology. Pages 54-59 in: 8th Ann. Rept. Scottish Horticultural Research Institute.

Castresana, J. 2000. Selection of conserved blocks from multiple alignments for their use in phylogenetic analysis. Mol. Biol. Evol. 17:540-552.

Codoñer, F. M., and Elena, S. F. 2008. The promiscuous evolutionary history of the family Bromoviridae. J. Gen. Virol. 89:1739-1747.

Da Costa Lima, M. L. R. Z., Lima Neto, V. C., and de Souza, V. B. V. 1991. The causal agent of ligustrum ringspot disease. (Abstr.) Phytopathology 81: 1216.

Dovas, C. I., and Katis, N. I. 2003. A spot nested RT-PCR method for the simultaneous detection of members of the Vitivirus and Foveavirus genera in grapevine. J. Virol. Methods 107:99-106.

Dupuis, L., Cobanov, P., Bassler, A., Krczal, G., and Wetzel, T. 2008. Complete genome sequences of a virulent isolate of Arabis mosaic virus from privet (Ligustrum vulgare). Arch. Virol. 153:1611-1613.

Edgar, R. C. 2004. MUSCLE: Multiple sequence alignment with high accuracy and high throughput. Nucleic Acids Res. 32:1792-1797.

Froussard, P. 1992. A random-PCR method (rPCR) to construct whole cDNA library from low amounts of RNA. Nucleic Acids Res. 20:2900.

Gorbalenya, A. E., Blinov, V. M., Donchenko, A. P., and Koonin, E. V. 1989. An NTP-binding motif is the most conserved sequence in a highly diverged monophyletic group of proteins involved in positive strand RNA viral replication. J. Mol. Evol. 28:256-268.

Hildebrand, E. M. 1953. Ringspot of privet in Texas. Plant Dis. Rep. 37:636.

Kitajima, E. W., Chagas, C. M., and Rodrigues, J. C. V. 2003. Brevipalpustransmitted plant virus and virus-like diseases: Cytopathology and some recent cases. Exp. Appl. Acarol. 30:135-160.

Kitajima, E. W., Rodrigues, J. C. V., and Freitas-Astua, J. 2010. An annotated list of ornamentals naturally found infected by Brevipalpus mite-transmitted viruses. Sci. Agric. (Piracicaba, Braz.) 67:348-371.

Koonin, E. V. 1991. The phylogeny of RNA-dependent RNA polymerases of positive-strand RNA viruses. J. Gen. Virol. 72:2197-2206.

Le, S. Q., and Gascuel, O. 2008. An improved general amino acid replacement matrix. Mol. Biol. Evol. 25:1307-1320.

Maliogka, V., Dovas, C. I., Efthimiou, K., and Katis, N. I. 2004. Detection and differentiation of Comoviridae species using a semi-nested RT-PCR and a phylogenetic analysis based on the polymerase protein. J. Phytopathol. 152: 404-409.

Marchler-Bauer, A., Zheng, C., Chitsaz, F., Derbyshire, M. K., Geer, L. Y., Geer, R. C., Gonzales, N. R., Gwadz, M., Hurwitz, D. I., Lanczycki, C. J., Lu, F., Lu, S., Marchler, G. H., Song, J. S., Thanki, N., Yamashita, R. A., Zhang, D., and Bryant, S. H. 2013. CDD: Conserved domains and protein three-dimensional structure. Nucleic Acids Res. 41:348-352.

Martelli, G. P., and Russo, M. 1984. Use of thin sectioning for the visualization and identification of plant viruses. Methods Virol. 8:143-224.

Pallas, V., Aparicio, F., Herranz, M. C., Amari, K., Sanchez-Pina, M. A., Myrta, A., and Sanchez-Navarro, J. A. 2012. Ilarviruses of Prunus spp.: A continued concern for fruit trees. Phytopathology 102:1108-1120.

Plakidas, A. G. 1959. Chlorotic spot, a graft-transmissible disease of Ligustrum. Plant Dis. Rep. 43:688-689.

Rozanov, M. N., Koonin, E. V., and Gorbalenya, A. E. 1992. Conservation of the putative methyltransferase domain: A hallmark of the 'Sindbis-like' supergroup of positive-strand RNA viruses. J. Gen. Virol. 73:2129-2134.

Sabanadzovic, S., and Abou Ghanem-Sabanadzovic, N. 2008. Molecular characterization and detection of a tripartite cryptic virus from rose. J. Plant Pathol. 90:287-293.

Sabanadzovic, S., Abou Ghanem-Sabanadzovic, N., and Gorbalenya, A. E. 2009. Permutation of the active site of putative RNA-dependent RNA polymerase in a newly identified species of plant Alpha-like virus. Virology 394:1-7.

Scott, S. W., and Zimmerman, M. T. 2008. The complete sequence of ligustrum necrotic ringspot virus, a novel carlavirus. Arch. Virol. 153:393-396.

Shimura, H., Masuta, C., Yoshida, N., and Sueda, K. 2013. The 2b protein of Asparagus virus 2 functions as an RNA silencing suppressor against systemic silencing to prove functional synteny with related cucumoviruses. Virology 442:180-188.

Talavera, G., and Castresana, J. 2007. Improvement of phylogenies after removing divergent and ambiguously aligned blocks from protein sequence alignments. Syst. Biol. 56:564-577. 
Tamura, K., Stecher, G., Peterson, D., Filipski, A., and Kumar, S. 2013. MEGA6: Molecular Evolutionary Genetics Analysis version 6.0. Mol. Biol. Evol. 30:2725-2729.

Thomsen, A. 1970. Virusinfektioner hos Ligustrum spp. Tidsskr. Planteavl 74: 234-241.

Tian, T., Klaassen, V. A., Soong, G. W., Wisler, J., Duffus, J. E., and Falk, B. 1996. Generation of cDNAs specific to lettuce infectious yellows closterovirus and other whitefly-transmitted viruses by RT-PCR and degenerated oligonucleotide primers corresponding to the closterovirus gene encoding the heat shock protein 70 homolog. Phytopathology 86:1167-1172.

Tzanetakis, I. E., Halgren, A. B., Keller, K. E., Hokanson, S. C., Maas, J. L. McCarthy, P. L., and Martin, R. R. 2004. Identification and detection of a virus associated with strawberry pallidosis disease. Plant Dis. 88: 383-390.

Vergani, A. R. 1942. La transmission de la lepra explosive de la ligustrina por acaros. Rev. Agric. Agron. 9:292-294. 